\title{
A ordem da missão e os jogos da ação: conflitos, estratégias e armadilhas na Amazônia do século XVIII
}

\author{
Almir Diniz de Carvalho Júnior[1]
}

\begin{abstract}
Resumo
Durante o século XVII, o processo de conquista espiritual e política das populações ameríndias na Amazônia foi conduzido pela Coroa Portuguesa e pelos missionários católicos divididos em várias ordens religiosas e sob a gerência dos Jesuítas. Este artigo aborda as estratégias políticas dos índios cristãos, no tempo dessas missões, a partir de um singular episódio que envolveu o jesuíta Antônio Vieira e o Principal indígena Lopo de Souza em meados do século XVII. O objetivo é revelar as complexas relações políticas e as estratégias de sobrevivência e de luta por espaços de autonomia desses índios, situados entre a vassalagem e a escravidão.
\end{abstract}

Palavras-chave: história indígena; história colonial da Amazônia; história cultural.

\section{La orden de misión y los juegos de acción: conflictos, estrategias y armadillas en la Amazonia del siglo XVII}

\section{Resumen}

En el siglo XVII, el proceso de conquista espiritual y política de las populaciones amerindias en la Amazonia fue conducido por la Corona Portuguesa y por los misionarios católicos, divididos en diversas órdenes religiosas y con la gerencia de los Jesuitas. Esto artículo aborda sobre las estrategias políticas de los indios cristianos en el momento de las misiones desde un único episodio que envolvió el jesuita Antônio Vieira y el Principal indígena Lopo de Souza durante el siglo XVII. El objetivo fue revelar las complejas relaciones políticas y las estrategias de sobrevivencia y de lucha por los espacios de autonomía de esos indios, situados entre la vasallaje y la esclavitud.

Palabras-clave: historia indígena; historia colonial de Amazonia; historia cultural.

\section{The order of the mission and action games: conflicts, strategies and traps in Amazon in the $17^{\text {th }}$ century}

\begin{abstract}
During the $17^{\text {th }}$ century, the spiritual and political conquest process of the Amazon Amerindian populations was led by the Portuguese Crown and catholic missionaries. These missionaries were divided into many religious groups and were under Jesuits' main control. This article is about the political strategies of Christian Indians, at the time of the catholic missions, analysed through a singular episode which involved the Jesuit Antônio Vieira and the Principal Indian Lopo de Souza in the middle of the $17^{\text {th }}$ century. The purpose is to bring out the complex political relationship, the surviving and fighting strategies for autonomy spaces from the Indians, who were placed between vassal order and slavery.
\end{abstract}

Keywords: indian history; Amazon colonial history; cultural history.

\section{L'ordre de la mission et des jeux d'action: les conflits, les stratégies et les pièges de l'Amazonie au XVIIIe siècle}

\section{Résumé}

Tout au long du XVIIe siècle, le processus de conquête spirituelle et politique des populations amérindiennes fut mené par la monarchie portugaise et par les missionnaires catholiques,divisés en divers ordres religieux, sous la gestion des Jésuites. Cet article examine les stratégies politiques des Indiens chrétiens à partir d ’un épisode singulier qui concerna le Jésuite Antônio Vieira et le Principal Indien, Lopo de Souza, vers la fin de la première moitié du XVIIe siècle. Le but en est de dévoiler les rapports politiques complexes et les stratégies de lutte et de survie de ces Indiens, placés entre la vassalité et l'esclavage, pour conquérir des espaces d'autonomie.

Mots-clés: histoire des indiens; histoire coloniale de Amazonie; histoire culturel.

Artigo recebido em 14 de março de 2013 e aprovado para publicação em 21 de maio de 2013.

[1] Departamento de História da Universidade Federal do Amazonas (UFAM) - Manaus (AM) - Brasil. E-mail: almirdcjr@yahoo.com.br 
conquista da Amazônia pelos portugueses envolveu guerras, alianças, conversões religiosas e negociações. Chegando à região, no início do século XVII, depois de expulsarem os franceses do Maranhão, os portugueses se viram envolvidos em vários outros confrontos. ${ }^{2}$ Combateram ingleses, irlandeses e holandeses durante toda a primeira metade do século XVII. Ao mesmo tempo, enfrentaram os Tupinambás do Maranhão que, aliados aos do Pará, infligiram quatro anos de luta aos conquistadores lusos. ${ }^{3}$ Este artigo aborda o início da tentativa de uma conquista mais profunda.

A interiorização da conquista pela religião veio sempre acompanhada pela conquista política. Portugueses e indígenas travaram um complexo jogo político desde o início do seu contato. Os estrategistas lusos, aos poucos, perceberam que aquela população de índios conhecia inovadoras técnicas de guerra e partilhava um sofisticado sistema de alianças. Dependendo do tipo de acordo ou aliança que com eles se estabelecessem, o apoio militar dessas populações poderia migrar para outra nação europeia. A fidelidade era conquistada com boa negociação e vantagens interessantes. ${ }^{4}$ A agência política foi parte fundamental da conversão dos indígenas ao cristianismo. Sem as alianças com essas populações, sem o jogo de interesses mútuos, sem o discurso de proteção dos missionários, talvez sequer um indígena abraçasse a nova religião. No jogo da conquista, os indígenas da Amazônia também foram protagonistas; eles não foram vítimas indefesas. Eles negociaram e sobreviveram criando sempre espaços de relativa autonomia.

Essa estreita autonomia, no entanto, não aconteceu sem violência. A violência sempre foi um ingrediente fundamental no sistema de controle e dominação. Não se pode perder de vista que o processo de transformação das comunidades indígenas tradicionais, praticado pelo projeto colonizador português e fruto das relações entre brancos e índios, correspondeu a uma arena de lutas que se instalou tanto no plano material quanto, e talvez de forma mais dramática, no plano espiritual e cultural.

Este artigo trata da tentativa de domínio espiritual que tomou corpo no decorrer da conquista política. A Amazônia então foi dividida entre diversas ordens religiosas na tentativa de dar conta da missão fundamental da conquista portuguesa: ganhar vassalos úteis e novas almas para Deus. Dentre essas ordens, a Companhia de Jesus dominava. Seus membros foram protagonistas dessa trama. No entanto, no cenário que será construído adiante, os personagens

\footnotetext{
Em 1621, o rei Felipe IV criou o Estado do Maranhão separado do Estado do Brasil. Abrangia todo o norte, boa parte do nordeste e parte do centro-oeste do atual território brasileiro.

${ }^{3}$ Almir Diniz de Carvalho Júnior, Indios Cristãos - a conversão dos gentios na Amazônia Portuguesa (16531769), Tese de Doutorado, Unicamp, Campinas, 2005, p. 39-83.

${ }^{4}$ Sobre a complexidade dos processos de negociação entre europeus e nativos, ver: Ronaldo Vainfas, Traição um jesuíta a serviço do Brasil holandês processado pela inquisição, São Paulo, Companhia das Letras, 2008 , em especial o capítulo "Imbróglio indígena". O autor analisa o drama do ex-jesuíta, aliado dos holandeses e, em seguida, peça-chave na reconquista de Pernambuco pelos portugueses - Manoel de Moraes. Nesse capítulo, o autor demonstra a importância da aliança entre os potiguaras e os holandeses, revelando alguns dos personagens indígenas que participaram dessa guerra.
} 
principais não se reduziram a esses homens de batina ou aos administradores coloniais. Nesse palco, também foram destaque os índios cristãos. ${ }^{5}$

\section{As Ordens religiosas na Amazônia portuguesa}

Os Franciscanos da Província de Santo Antônio foram os primeiros a chegar ao mundo amazônico. Logo em seguida, vieram os missionários da Companhia de Jesus. Com o tempo, chegaram a Ordem dos Carmelitas e dos Mercedários. Outras províncias dos franciscanos também aportaram em solo amazônico: os Capuchos da Piedade e, por fim, os Frades da Conceição da Beira e Minho. O Estado português os financiava e, em contrapartida, as ordens se responsabilizavam pela catequese do gentio e pela assistência intelectual e espiritual aos colonos. ${ }^{6}$

As obrigações em converter o gentio não se restringiam ao âmbito espiritual. Fazia parte do programa de conversão modificações profundas no seu comportamento, como: a erradicação de seus hábitos de nomadismo; o preparo técnico para trabalhos nos ofícios mecânicos; a mudança na organização espacial de suas antigas tribos, transformando-as em núcleos urbanos; a criação de um regime de trabalho disciplinado e de base agrícola; por fim, a reforma dos seus modos de vida social, criando a estrutura e os vínculos da família cristã. O objetivo maior desse "projeto de conversão" era transformá-los em vassalos úteis e cristãos. ${ }^{7}$

Na opinião de Ferreira Reis, a necessidade do estabelecimento das missões na Amazônia deveu-se também ao receio, por parte da Coroa, da influência e do domínio dos calvinistas franceses e reformistas ingleses, holandeses e irlandeses que passaram a se localizar ao longo do litoral leste-oeste, colocando em perigo os interesses mercantis e políticos dos portugueses na região. $\mathrm{O}$ temor maior era a relação que as outras nações passaram a estabelecer com as populações indígenas, doutrinando-as sobre outras diretrizes espirituais. Por essas e por outras razões, era unânime para os primeiros conquistadores da região a necessidade do apoio das ordens missionárias para o domínio e controle definitivos daquela massa nativa. ${ }^{8}$

Para fazer frente a essa tarefa, foi concedido às primeiras ordens religiosas que por ali chegaram o governo temporal daquelas populações indígenas, sem

\footnotetext{
5Os "índios cristãos" enquadravam-se numa chave identitária genérica, mas bem delimitada. Definiam de forma concreta os limites dessa identificação. Somente os batizados poderiam ser "cristãos" e somente os "índios" entram nessa categoria. Compunham-se de etnias diversas em sua origem, mas definiam um tipo de inserção social particular. A apropriação dessa identidade significou a resposta inovadora que as populações ameríndias deram ao projeto colonizador. Era uma forma de domarem seu destino. Ser cristão, antes de ser um enquadramento genérico, era uma decisão - fruto de sua agência. Ver: Almir Diniz de Carvalho Júnior, Indios Cristãos - a conversão dos gentios na Amazônia Portuguesa (1653-1769), Tese de Doutorado, Unicamp, Campinas, 2005.

${ }^{6}$ Essa antecedência dos franciscanos não inclui o Maranhão, onde os jesuítas anteciparam-se a eles. Ver: Carlos Araújo Moreira Neto, "Os principais grupos missionários que atuaram na Amazônia brasileira entre 1607 e 1759", In: Eduardo Hoornaert (org.), História da Igreja na Amazônia, Petrópolis, Vozes, 1992, p. 65-66. ${ }^{7}$ Arthur Cezar Ferreira Reis, A Conquista Espiritual da Amazônia, 2. Ed., Manaus, EDUA/Governo do Estado do Amazonas, 1997, p. 8.

8/dem, Ibidem, p. 2-6.
} 
o qual, reclamavam os missionários, seria extremamente difícil a realização de sua missão. Embora essa concessão tenha sofrido reveses, em linhas gerais, a participação das ordens religiosas no domínio temporal de seus novos catecúmenos prevaleceu em detrimento dos conflitos entre os vários interesses das outras parcelas da população colonial na região que, em alguns momentos, conseguiram para si a concessão desse direito.

\section{Vieira afirmava o caráter especial de sua Companhia em comparação às outras ordens que atuavam na Amazônia. Naquele momento, os jesuítas haviam sido expulsos do estado do Maranhão}

Franciscanos, Mercedários, Carmelitas e suas ramificações tiveram um papel fundamental na balança dos interesses que se dividiam entre a Coroa e os moradores. A Coroa portuguesa precisava manter o controle geopolítico sobre a região, transformando-a também num entreposto comercial importante para a riqueza do império. Por outro lado, os interesses econômicos dos moradores entravam em choque, muitas vezes, com a necessidade de se manterem os nativos aliados, transformando-os em súditos fiéis. Os missionários prestavam serviços essenciais tanto a uns quanto a outros. No entanto, essas ordens citadas sucumbiam com facilidade aos interesses locais e a sua fragilidade institucional era visível se comparada aos soldados de Cristo, a Companhia de Jesus. Esta última ordem, ao contrário das primeiras, servia com mais "fidelidade" à Coroa e, ao mesmo tempo, aos seus próprios interesses institucionais.

\section{Jesuítas - as estrelas de Cristo}

Desses soldados de Cristo, aquele que se confundiu com a própria fundação da Ordem na Amazônia foi o padre Antônio Vieira. É dele este belo trecho onde destaca as particularidades da instituição de quem era o melhor arauto. Falava do púlpito da capela real em Lisboa, em 06 de janeiro de 1662, tendo como sua mais ilustre ouvinte a rainha D. Luísa - na época, regente do Império, devido à recente morte do rei D. João IV, grande amigo e protetor de Vieira. Referia-se à recente expulsão de que fora vítima nas terras do Maranhão. Neste trecho, faz menção à estrela que guiou os reis magos ao encontro de Jesus recém-nascido:

Que ofício foi o daquela Estrela? Alumiar, guiar e trazer homens a adorar a Cristo, e não outros homens, senão homens infiéis e idólatras, nascidos e criados nas trevas da Gentilidade. Pois esse mesmo é o ofício e exercício não de quaisquer Pregadores, senão 
daqueles Pregadores de que falamos, e por isso propriamente Estrelas de Cristo [...] Todas as outras Estrelas não são, também, Estrelas de Cristo, que, como Deus as criou? Sim, são. Pois por que razão esta Estrela mais que as outras se chama especialmente Estrela sua: Stella ejus? Porque as outras Estrelas foram geralmente criadas para tochas do Céu e do mundo; esta foi criada, especialmente para Pregadora de Cristo [...]. Muitas outras Estrelas há naquele Hemisfério, muito claras nos resplendores e muito úteis nas influências, como as do Firmamento; mas estas de que falamos, são própria e especialmente de Cristo, não só pelo nome de Jesus, com que se professam por suas; mas porque o fim, o instituto, e o ofício para que foram criadas, é o mesmo que o da Estrela dos Magos, para trazer Infiéis e Gentios à Fé de Cristo. ${ }^{9}$

Com a maestria que lhe era peculiar, Vieira afirmava o caráter especial de sua Companhia em comparação às outras ordens que atuavam na Amazônia. Naquele momento, os jesuítas haviam sido expulsos do estado do Maranhão. Era o fim do primeiro período de atuação dessa ordem naquelas terras. Não foi por acaso que as outras ordens foram chamadas pelas autoridades locais para se estabelecerem na Amazônia, também não foi por acaso que os jesuítas foram de lá expulsos por duas vezes, em 1661 e em 1684. Nos anos iniciais da missão, fica clara a contradição de interesses entre os objetivos da Companhia de Jesus, os dos moradores e os das autoridades coloniais. Em consequência, como não era possível prescindir do missionário no processo de dominação das massas indígenas, as autoridades coloniais estabeleceram com as outras ordens relações mais próximas, impondo seus interesses e limitando sua atuação.

É certo que o papel de Vieira para o acirramento dessa situação de conflitos de interesses não foi dos menores. Ele fundou a missão no Maranhão e Pará e tinha por ela um apreço especial. Abandonou os favores da corte para se lançar nessa missão que sabia ser difícil. Do início da fundação da missão em 1653 até o ano de 1661, Vieira detinha um poder invejável: amigo e confidente do rei, ele era, por isso, temido e respeitado. Em consequência, tanto na corte quanto na colônia, cultivou inimigos. Ademais, sua retórica era arma poderosa que usava sem medo quando lhe parecia necessário, deixando atônitos seus adversários. É até possível seguir a instituição da missão jesuíta na Amazônia sob o ritmo dos seus sermões.

Chegando a São Luís, em 1653, pregou o Sermão das Tentações, por meio do qual falava contra a escravização dos índios. Depois de ter iniciado seu primeiro contato com os nativos amazônicos, quando da sua ida ao rio Tocantins para instalar a missão, no seu retorno ao Maranhão pregou o Sermão de Santo Antônio aos Peixes. Por meio dele, atacou as autoridades coloniais, usando para isso a imagem dos habitantes aquáticos. Assumia dessa forma o caráter que o marcaria ao longo de sua trajetória naquela região - não iria contemporizar.

9Antônio Vieira, "Sermão da Epifania", In: Alcir Pécora (org.), Antônio Vieira - Sermões, Tomo I, São Paulo, Hedra, 2003, p. 605. 
Naquele sermão, atacava com veemência os cativeiros injustos. Com essa sua atitude, ganhou para si inimigos poderosos na colônia que iriam posteriormente articular a expulsão da Ordem daquelas terras.

Naqueles anos, o poder de Vieira estava intacto. Logo após esse sermão, embarcou para a Corte, onde pregou outro na Capela Real: Sermão da Palavra de Deus. Nele, apontava as dificuldades da missão no Maranhão. Com seu poder de persuasão, conseguiu apoio que se concretizou na lei de 09 de abril de 1655 sobre a liberdade dos índios. Voltou então triunfante ao Maranhão e Pará, acompanhado do novo governador, André Vidal de Negreiros, escolhido pelo rei sob sua orientação. Durante os seis anos posteriores, tentou colocar em prática seu projeto de doutrinação. Vidal de Negreiros tornou-se seu aliado mais forte e, por meio de sua ajuda, conseguiu seus objetivos. Entre 1658 e 1660, escreveu o "Regulamento das Aldeias", mais conhecido como a "Visita de Vieira". Por meio desse documento, estabeleceu as diretrizes da missão na Amazônia. Tais orientações, com pouquíssimas mudanças, acabaram vigorando por mais de um século. Esse documento tratava mais diretamente do cotidiano da ação missionária, envolvendo desde a forma da doutrina até a disposição do espaço de moradia dos missionários e índios. Não eram regras apenas para serem seguidas pelos jesuítas, senão por todas as outras ordens. Ao mesmo tempo, a lei de 1655 dava primazia absoluta à Companhia de Jesus quanto à catequese dos indígenas. ${ }^{10}$

Expulsos os jesuítas em 1661, Vieira, num último esforço, pregou outro sermão, do qual se destacou o trecho acima, que ficou conhecido como o "Sermão da Amazônia", formalmente intitulado "Sermão da Epifania". A rainha D. Luíza, embora tocada pelas ideias do orador, não pôde mais ajudá-lo. Ela foi deposta e em seu lugar ascendeu ao trono D. Afonso VI. Francamente contrário a Vieira, o novo rei aprovou a lei de 12 de setembro de 1663, revogando a de 1655 e tirando dos jesuítas a primazia da administração temporal dos índios. Com a nova lei, as Câmaras de Belém e de São Luís passavam a controlar essa administração.

Vieira caiu em desgraça e foi preso pelo Tribunal da Inquisição. Permaneceu preso entre 1663 e 1667. Mas, embora tendo sido vencido naquele momento, voltou à ação novamente. Não podia mais voltar ao Maranhão, mas de longe ainda influenciou a lei de $1^{\circ}$ de abril de 1680 , que pregava a liberdade dos índios e era favorável aos jesuítas. A consequência dessa lei também foi um conflito que estourou em 1684, culminando com a nova expulsão dos padres da Companhia. Depois da revolta de 1684, conhecida pela historiografia como a "Revolta de Beckman", nova lei se estabeleceu esta fadada a persistir. Tratava-se do "Regimento das Missões do Estado do Maranhão e Grão-Pará”, lei de 21 de dezembro de 1686. O Regimento inaugurou um novo momento das missões religiosas na Amazônia e também

10Sobre o "Regulamento das Missões", ver: Almir Diniz de Carvalho Júnior, “A Doutrinação dos Gentios", In: Indios Cristãos - a conversão dos gentios na Amazônia Portuguesa (1653-1769), Tese de Doutorado, Unicamp, Campinas, 2005, p. 158-171. 
um novo momento para a Companhia de Jesus. A influência de Vieira perdeu força e ganhou lugar o pragmatismo. ${ }^{11}$

As pretensões de Vieira em transformar a Companhia de Jesus em "estrela guia" cedeu lugar às circunstâncias do trabalho missionário naquela região. As "estrelas de Cristo" perderam seu brilho para que pudessem continuar no firmamento. Ainda assim, permaneceram com esplendor, conduzindo, de certa forma, as outras "estrelas" no sentido que lhes convinha.

\section{Os jesuítas e o controle das primeiras missões}

Embora os jesuítas tivessem chegado ao Maranhão em 1615, o controle efetivo sobre a administração dos índios só veio com Vieira. Antes disso, sua função se reduzia a catequizar as aldeias que visitavam. Luiz Figueira iniciou a conversão no ano de 1639. No entanto, em 1643, ele e outros jesuítas sofreram um naufrágio e foram martirizados. ${ }^{12}$

Não foi fácil efetivar a missão nos anos posteriores. Em 1649, novos missionários também foram mortos pelos índios. Foi somente no ano de 1652 que finalmente teve início a missão com a chegada de outros jesuítas enviados por Antônio Vieira, então superior de todas as missões.

Vieira veio em seguida, no ano de 1653. Aportou no mesmo ano da publicação da Ordem Régia levada pelo capitão-mor do Maranhão. Por essa ordem, em que se pode encontrar o dedo do jesuíta, o capitão punha em liberdade todos os índios até então cativos. Entretanto, Antônio Vieira pôde sentir, nessa sua chegada, a animosidade que prevalecia entre os moradores em relação à Companhia. Foi o que revelou em carta para a Bahia, referindo-se às novas ordens trazidas pelo capitão-mor. Destacava o motim público que se seguiu nas ruas, na Câmara, na praça. Entre armas e muita confusão, a pena de Vieira traça, em singular ironia, a ação da população em revolta: “[...] resolutos todos a perder antes a vida (a alguns houve que antes deram a alma) do que consentir que se lhes houvessem de tirar de casa os que tinham comprado por seu dinheiro." ${ }^{13}$

Diz Vieira que as labaredas que se iniciaram foram alimentadas por aqueles que tinham por obrigação apagá-las. Referia-se às outras "religiões": “[...] os da mesma profissão sejam de ordinário os mais apaixonados contra nós; [...] e ofende-lhes os olhos tanta luz na Companhia." ${ }^{14}$ Talvez estivesse já em germe a imagem da "estrela guia" dos jesuítas, tão bem

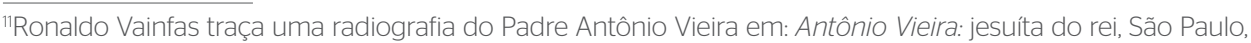
Companhia das Letras, 2011. Ele delineia um perfil do jesuíta com base em densa bibliografia e escritos do próprio padre. Dentre outros aspectos, discute o caráter singular desse jesuíta relacionado não somente ao grande poder que galgou em razão de sua proximidade com o rei restaurador D. João IV, mas também ao mistério de sua origem mulata, aos seus escritos proféticos e ao seu enorme talento para seduzir plateias e cultivar inimigos com seus sermões.

12Sobre a chegada dos jesuítas no Maranhão, ver: José de Morais, História da Companhia de Jesus na extinta província do Maranhão e Pará [1759], Rio de Janeiro, Editorial Alhambra, 1987, p. 78-80.

${ }^{13}$ Antônio Vieira, apud Serafim Leite, História da Companhia de Jesus no Brasil, Tomo IV, Lisboa/Rio de Janeiro: Portugália/Civilização Brasileira, 10 v., 1938-1950, p. 45.

14/dem, Ibidem, p. 46
} 
descrita no Sermão da Epifania. Ofuscadas então pela poderosa "luz" da Companhia, é provável que as outras ordens religiosas seguissem regras distintas naquele jogo de poder.

Vieira recuou estrategicamente. O capitão-mor recebeu uma proposta assinada pelas autoridades locais, pelos religiosos e pelo povo do Estado que defendia: a legitimidade dos cativos, que as entradas e resgates no sertão eram lícitos - pois os "índios bárbaros" eram "a pior gente do mundo" e, em liberdade, levantar-se-iam contra os portugueses. Na proposta, ainda contava a mais importante das razões: a "república" não podia se sustentar sem os índios.

Segundo Vieira, esse documento foi assinado pelos prelados de todas as "religiões" e pelos dois vigários. Os jesuítas foram convocados a assinar também o mesmo documento, mas recusaram. Seguiu-se outro motim. Essa primeira batalha de Vieira indica a dificuldade que o projeto catequético jesuítico teve diante da realidade da colônia. Ainda em outubro de 1653, o rei acabou por ceder às pressões dos moradores do Maranhão, expedindo outra lei que, revogando a anterior, era mais favorável aos cativeiros. ${ }^{15}$

Nessa época, Vieira já havia feito sua primeira entrada pelos sertões em direção ao rio Tocantins. Com a experiência adquirida, percebeu quais os problemas que a utilização dos índios como escravos poderia trazer para a conversão dos gentios e para os interesses da Coroa. A grande dificuldade que sentiam os jesuítas nas aldeias sob sua administração é que não tinham poder para deter a retirada dos índios para os trabalhos dos moradores, o que, para Vieira, dificultava, senão tornava impossível a sua doutrinação.

Nas aldeias, a ausência dos índios era constante para os trabalhos do tabaco, deixando-as despovoadas por oito ou nove meses por ano. Além do tabaco, os índios eram utilizados para pescarias, em busca do cravo, breu, na confecção de estopa, para fabricar navios etc. Com isso, o tempo de ausência chegava a ser, por vezes, de dois ou três anos. Vieira também denunciava que havia momentos em que aldeias inteiras eram levadas para o trabalho em engenhos e fazendas de açúcar das autoridades coloniais. Os jesuítas se viam sem poder para impedir quando algum sargento ou cabo de esquadra, com ordem do capitão-mor aos principais, chegava para dispor dos índios e índias. Vieira chegou a afirmar que a escravidão era encarada por esses índios com menos pesar do que a "liberdade" que tinham nas aldeias. Faziam isso, segundo ele, misturando-se aos escravos dos portugueses, vivendo e casando-se com eles para fugir da vida nas aldeias, quando não fugiam para o interior dos sertões, conforme as palavras do jesuíta:

[...] outros, em que havia mais brio e valor, se perdiam entre os Gentios, e com as novas que lhes levavam, os retiravam da fé, e os confirmavam na vida que tinham e na resolução de se não quererem sujeitar nunca aos Portugueses. ${ }^{16}$

15/dem, Ibidem, p. 50-51

${ }^{16}$ Antonio Vieira, apud Serafim Leite, História da Companhia de Jesus no Brasil, Tomo IV, Lisboa/Rio de Janeiro: Portugália/Civilização Brasileira, 10 v., 1938-1950, p. 52. 
Com essa experiência inicial, partiu Vieira para a Corte, levando consigo três resoluções que permitiriam, em sua opinião, a efetivação da conversão. Eram elas: primeiro, que não se fizesse guerra ofensiva aos gentios, mas apenas se resgatassem deles os escravos legítimos; segundo, que os índios cristãos e vassalos não podiam ser constrangidos a servirem mais do que o tempo da lei e que, no restante, permanecessem livres, sendo governados pelos seus principais e pelo pároco que deles cuidassem; terceiro, que os missionários, ao instalarem suas missões nos sertões, o fizessem livremente, sem dependência dos governantes, cabendo ao Superior das missões a escolha dos cabos das jornadas. Como já mencionado, sua vitória na Corte foi coroada pela lei de 1655.

Como se sabe, essa vitória foi curta. Em 1661, Vieira, fragilizado pela partida do seu grande aliado para a África, o governador André Vidal de Negreiros, e diante de diversas acusações promovidas pelas Câmaras das duas capitanias, foi expulso definitivamente do Maranhão e do Pará. Das acusações contra Vieira, duas delas se destacam. Uma refere-se a cartas que havia mandado ao rei pelo bispo do Japão, interceptadas pelos religiosos Carmelitas e colocadas por estes a público. Nelas, o jesuíta acusava o não cumprimento, por parte da população daquele estado, das leis contra a escravização dos índios. Outra acusação referia-se ao fato de Vieira ter mandado prender ao Principal índio Lopo de Souza Guarapaúba - essa era a mais interessante. ${ }^{17}$

A primeira acusação revela os enormes conflitos que se estabeleciam entre as Ordens Religiosas. Mostra também qual o partido tomado por elas nesse jogo de forças. A segunda é muito mais contundente, porque atingia os jesuítas no que tinham de mais caro - sua pretensa defesa incondicional das populações indígenas. Revela, ao mesmo tempo, quão complexa era a forma com que os índios cristãos traduziam as relações que estabeleciam com a população europeia colonial - fossem padres ou leigos. Vieira, de certa forma, deixa escapar nos seus relatos citados acima que os próprios índios decidiam fugir das aldeias para se integrarem à "casa" de proprietários de escravos, tornandose um deles - sintoma desse intrincado jogo de relações.

A prisão do Principal foi relatada pelo próprio Vieira, quando respondeu, em carta ao rei, sobre as acusações de que fora vítima. Afirmava que o tal Principal não obedecia às leis de Sua Majestade e que, para isso, era amparado pelos poderosos a quem prestava serviços. O que parecia incomodar Vieira, no entanto, era que o Principal e os seus viviam como gentios: "[...] sendo cristãos mui antigos, porque, além das muitas amigas que tinha o dito

\footnotetext{
${ }^{17}$ Esse episódio da expulsão de Vieira envolvendo o Principal Lopo já foi citado por outros autores. Em especial, destaco: João Lúcio de Azevedo, Os Jesuítas no Grão-Pará: suas missões e a colonização [Facsim, ed. 1901], Belém: SECULT, 1999, p. 78. Mais recentemente, foi mencionado por John Hemming, Ouro Vermelho: a conquista dos índios brasileiros; trad. Carlos Eugênio Marcondes de Moura, São Paulo: EDUSP 2007, p. 490-491. Em ambos os casos, os autores apenas citam o ocorrido sem mergulhar mais a fundo nas contradições das diversas versões do evento e também pouco diferem da versão de Serafim Leite, em obra citada logo em seguida neste texto. Aqui utilizamos um conjunto de documentos que demonstram outras versões do ocorrido e desnudam a ação dos ameríndios nesse importante conflito.
} 
Principal, estava casado in facie ecclesiae com uma irmã de outra de quem antes do matrimónio (sic) tinha publicamente filhos". Vieira acusava-o então de não seguir os preceitos da doutrina cristã: ele não ia à missa ou seguia qualquer dos sacramentos. Esses índios cristãos, segundo o jesuíta, morriam sem confissão como gentios. Acusava também o Principal de cativar índios livres e vendê-los. Por fim, afirmava que: “[...] outros mandava matar a modo e com cerimônias gentílicas". Para Vieira, aqueles que o deveriam castigar não o faziam "por interesses vilíssimos." ${ }^{18}$

O conflito entre os interesses da Companhia de Jesus e os de algumas lideranças indígenas - incluindo a prisão do Principal Lopo de Souza - mostra a ponta de um iceberg. As populações indígenas não eram indiferentes aos missionários que com elas mantinham contato: ao tomarem o partido de uns em detrimento de outros, levavam em consideração interesses particulares. Embora os jesuítas tivessem primazia para alguns, havia também partidários de outras ordens. Havia mesmo os que preferiam a administração de um leigo - ainda que isso os tornasse escravos. Portanto, não é tão simples compreender o processo da administração das populações indígenas quando se procura focar o objeto dela - os índios, em particular os cristãos. ${ }^{19}$

O caso de Lopo de Souza não somente exemplifica o conflito de interesses entre a Companhia de Jesus e as populações indígenas, mas coloca também em relevo a contradição entre os interesses jesuíticos, das outras ordens religiosas e das autoridades coloniais. De certa maneira, esse episódio sintetiza as contradições, ao demonstrar em minúcias os meandros das relações complexas que se produziam no universo colonial a cada decisão emanada da Coroa ou dos seus mais fiéis aliados naquele momento: os jesuítas. No entanto, ainda que os interesses da Companhia se confundissem em alguns momentos com os dos monarcas portugueses, iam muito além destes. A prisão desse Principal pode revelar muito mais do que uma conspiração para a expulsão da Companhia ou do que interesses vis que atentavam contra a fé, como faz crer Vieira em seus escritos. A voz intermediada desses índios que surge na documentação traz outra versão e faz compor essa teia de relações com novas nuanças, alçando essas populações também ao patamar de protagonistas dessa trama.

\footnotetext{
${ }^{18}$ Antonio Vieira, apud Serafim Leite, História da Companhia de Jesus no Brasil, Tomo IV, Lisboa/Rio de Janeiro: Portugália/Civilização Brasileira, 10 v., 1938-1950, p. 55-56.

${ }^{19}$ Diversos trabalhos têm revelado formas criativas e inovadoras dessas populações na busca por espaços de autonomia. A historiadora Elisa Frühauf Garcia revela como os índios das missões do sul do Brasil, em contato e negociação com os portugueses, influenciaram, por meio de sua agência política, a produção das políticas indigenistas do Império Lusitano. In: As diversas formas de ser Indio - políticas indígenas e políticas indigenistas no extremo sul da América portuguesa, Rio de Janeiro, Arquivo Nacional, 2009. Para a região do atual Rio de Janeiro, o importante trabalho da historiadora Maria Regina Celestino de Almeida sob o título Metamorfoses Indígenas - identidade e cultura nas aldeias do Rio de Janeiro, Rio de Janeiro, Arquivo Nacional, 2003 desvenda os caminhos até então ocultos da participação das populações ameríndias na construção do Rio de Janeiro colonial, explorando o processo de transformação de parte dessas populações em súditos da Coroa, inclusive no quadro da nobreza colonial. Outros trabalhos têm surgido nos últimos anos sob a batuta de John Manuel Monteiro, que, a partir da publicação de seu hoje clássico Negros da Terra - índios e bandeirantes na origem de São Paulo, São Paulo, Companhia das Letras, 1994, orientou novas pesquisas que vêm incorporando as populações ameríndias como protagonistas na história do Brasil. Para acessar essas novas contribuições, ver: www.ffch.unicamp.br/ihb/
} 


\section{Um índio cristão inimigo de Vieira}

O Principal Lopo de Souza Guarapaúba não era um homem jovem. Deveria ter em torno de 60 ou 70 anos. Lutara na guerra de reconquista da região e, como prêmio, recebeu do rei o hábito de Cristo. Já em 1647, se tem notícia dele. Na época, assinou um termo em que prometia fidelidade aos brancos na figura do donatário da capitania do Caeté. Ele e os seus foram convidados a "descer" e lhes prometeram batizá-los católicos. Além disso, seriam pagos por seus trabalhos ao servirem ao donatário e aos brancos moradores da vila de Santa Tereza. ${ }^{20}$

Ele comandaria 11 anos depois, juntamente com seus filhos, uma das aldeias mais importantes do Pará. A aldeia do Maracanã era estratégica para a região por dois motivos. Em primeiro lugar, em suas imediações, se encontravam as salinas do rei que forneciam o sal para a capitania. Essa aldeia, além de trazer importantes lucros para a Fazenda Real, também abastecia a cidade do Pará. Em segundo lugar, era um entreposto de passagem que dava auxílio para as embarcações que iam do Pará para o Maranhão e viceversa. Auxiliava, com remeiros e principalmente com guias, os que navegavam naquele trecho. Esses guias eram indispensáveis para os barcos que se deslocavam entre as duas capitanias.

O episódio da prisão de Lopo de Souza por Vieira revela muito mais do que fez crer o jesuíta e põe às claras o intrincado jogo de relações que havia entre os diversos personagens envolvidos. A versão de Vieira, quando comparada com a dos índios da aldeia e dos religiosos do Santo Antônio, das Mercês e do Carmo sobre o mesmo episódio, apresenta-se, no mínimo, parcial - para não dizer inverídica.

A repercussão da prisão do Principal da aldeia do Maracanã foi muitíssimo maior do que deixam escapar os escritos de Vieira. O episódio começou a tomar vulto quando os índios da aldeia do Maracanã entraram com uma petição contra a prisão do seu Principal junto ao Ouvidor Geral e provedor-mor da fazenda do rei no Estado, o licenciado Diogo de Souza e Menezes. Essa petição chegou às mãos do escrivão em 24 de abril de 1661, juntamente com outra da Câmara do Pará e uma carta, pretensamente escrita pelo padre Vieira e endereçada ao Principal Lopo de Souza. Na carta, contam os índios, Vieira pedia ao Principal que seguisse em companhia do padre Francisco Veloso, o que, segundo o mesmo documento, "como leal e fiel Vassalo assim da Igreja como de Sua Majestade, se abalou logo sem dilação alguma, em companhia do dito Padre". Segue outro trecho da petição dos índios:

${ }^{20}$ Sociedade Geográfica de Lisboa (SGL), Códice I, Res 2 - E, f. 69v - 70. 
[...] não reparando nos muitos achaques que por sua velhice padecia, e sendo chegado a dita cidade, indo ao colégio dela buscar e falar ao dito Reverendo Padre Antônio Vieira, e entrando da portaria para dentro os aplausos com que o receberam, foi com o desarmar de suas armas, e lhe tirarem o Hábito de Cristo de que Sua Majestade lhe fez mercê, e fazendo de uma cela corcel privado o meteram nela com um grilhão nos pés, aonde esteve alguns dias, e dali foi levado para o Forte do Gurupá, donde ele Suplicante até o presente não tem notícia do mais que lhe tem feito, e do referido não sabem a causa nem razão porque se lhe fez semelhantes agravos, e injustiças, por não terem incorrido em culpa alguma do serviço de Deus e de Sua Majestade do qual foi sempre grande servidor assim da conquista e restauração deste Estado [...]. ${ }^{21}$

A petição segue e demonstra o conhecimento que esses índios cristãos tinham de sua importância no cenário político e econômico do Estado. Argumentam que sempre serviram aos interesses do rei zelando pelas salinas reais, com as quais abasteciam toda a região circunvizinha. Diante do ocorrido, afirmam que se perderiam as salinas e o apoio que davam para a navegação entre as duas capitanias pertencentes ao Estado. Observam ainda que sempre socorriam com farinha, peixe e carne o regimento de infantaria instalado na fortaleza da Capitania do Pará. Tudo, no entanto, iria acabar devido à falta que o seu Principal fazia para a aldeia, já que toda a gente da aldeia e outras vizinhas de seus parentes iriam se ausentar para os matos devido à afronta que tinham feito ao seu Principal. Argumentam que teria sido sem causa ou delito algum que ele tivesse cometido contra a Igreja de Deus.

A percepção aguda desses índios sobre os intrincados trâmites legais se mostra quando questionam a legalidade da atitude do jesuíta. Afirmam que, caso realmente seu Principal tivesse infringido alguma regra da Igreja, esse delito deveria ser julgado pelo Vigário Geral que, na opinião deles, era quem de direito poderia julgar e aplicar o castigo necessário à falta. Por outro lado, se a falta fosse contra o serviço de Sua Majestade, caberia ao governador julgá-la e aplicar a devida pena, caso culpado fosse. Os índios mencionam ser notório que o seu Principal nunca desobedecera às ordens do governador, tendo sido sempre um leal súdito e vassalo de Sua Majestade. Em razão disso, pedem que o governador, em respeito a sua representação, ordenasse à infantaria e à justiça do Pará e do Gurupá que trouxessem o seu Principal à presença do mesmo, para que este verificasse suas culpas ou a falta delas, mandando o que lhe parecesse de justiça. Dessa forma, diziam, seriam evitados os inconvenientes ao serviço de Deus e de Sua Majestade. ${ }^{22}$

Dando encaminhamento à petição dos índios e à da Câmara do Pará, o governador solicitou a seu Ouvidor Geral que fizesse uma diligência, colhendo informações sobre o caso das pessoas que viessem do Pará. Naquele

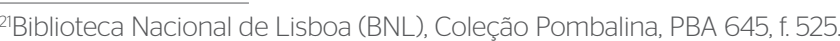

${ }^{22}$ Idem, Ibidem 
momento, a sede do governo estadual era em São Luis do Maranhão. ${ }^{23} \mathrm{O}$ Ouvidor, depois de ouvir as testemunhas, daria o seu parecer. Não seria difícil encontrar essas pessoas, já que Maracanã era rota de passagem entre as duas capitanias e o movimento de canoas entre as duas sedes era muito grande. Foram ouvidos: Frei João das Neves, comissário dos religiosos de Santo Antônio; Frei Manoel da Encarnação, vigário provincial dos carmelitas; Frei Marcos da Natividade, vigário provincial da ordem dos mercedários; Domingos Fialho, que foi almoxarife da fazenda real de Sua Majestade na capitania do Pará e morador da capitania; Antônio de Mattos de Sampaio e o Capitão reformado Bernardo Varella de Bulhões.

Depois de ouvidos os depoimentos, o Ouvidor Geral emitiu um parecer e o governador Pedro de Mello, outro. Consta desse processo, além dos depoimentos das testemunhas, das duas petições dos índios e da Câmara e dos termos respectivos, uma carta que teria sido escrita por Vieira, endereçada ao Principal Lopo de Souza, e uma carta do governador enviada ao jesuíta, na qual relata os fatos ocorridos na aldeia e expõe ao Superior dos jesuítas o seu parecer.

\section{As populações indígenas não eram indiferentes aos missionários que com elas mantinham contato: ao tomarem o partido de uns em detrimento de outros, levavam em consideração interesses particulares}

Os depoimentos de todas as testemunhas confirmam que a referida aldeia por onde passaram estava conturbada e seus habitantes resolvidos a abandoná-la, caso não fosse tomada qualquer providência para livrar o seu Principal e seu sargento-mor, que também fora preso pelos jesuítas.

Frei João das Neves, comissário dos franciscanos de Santo Antônio, afirmou que, estando em companhia do provincial dos carmelitas e outros religiosos vindos do Pará para o Maranhão, parou na aldeia do Maracanã para buscar o necessário ao restante da viagem e também em busca de um guia. Segundo o religioso, o Principal Lopo de Souza, juntamente com seus filhos, havia "doutrinado" os índios que sempre recebiam bem aos brancos, auxiliando-os quando estes buscavam farinhas e mantimentos para suas viagens. Mas, quando passou por lá, percebeu-os alterados e decididos a abandonar a aldeia e irem para os matos. Consideravam a prisão de Lopo de Souza injusta e acreditavam que ele teria sido traído. O comissário tentou sossegá-los, dizendo-lhes que logo mandariam vir o seu Principal. Responderam então que, caso libertassem seu líder, não mais partiriam da aldeia. $O$ frei conta também que testemunhou que o Principal, várias vezes, tocava até mesmo o sino da igreja da aldeia, para chamar seus filhos. Depois, ele vinha com

$\overline{{ }^{23} V i e i r a ~ c o n s e g u i u ~ d o ~ r e i ~ a ~ u n i f i c a c ̧ a ̃ o ~ d o ~ g o v e r n o ~ d o ~ E s t a d o, ~ t e n d o ~ c o m o ~ s e d e ~ S a ̃ o ~ L u i ́ s . ~ A n t e s ~ d i s s o, ~ a s ~}$ capitanias tinham autonomia administrativa. 
seus cavaleiros para que lhes fossem feitas as doutrinas. Isso demonstrava, segundo o religioso, seu esforço para que seus índios conhecessem a Deus. Acreditava também que a produção do sal ficaria prejudicada porque não havia outros índios que soubessem trabalhar o produto como aqueles que foram, para isso, bem "doutrinados" pelo seu Principal. Quanto ao comércio, não haveria outra aldeia naquele caminho que pudesse servir de préstimo para quem se movimentasse entre as duas capitanias. ${ }^{24}$

Frei Manoel da Encarnação — provincial dos carmelitas — disse que, estando no Convento do Carmo, no Pará, teria vindo até ele um índio de nome Tomé, capitão da aldeia do Maracanã, dizendo que, em função de o Padre Vieira ter prendido o seu Principal, vinha se ocultar no convento. Pelas informações prestadas pelo índio, sabia que tinham colocado o Principal em grilhões no colégio do Pará e não permitiam que recebesse visita. Em seu depoimento, também disse o que vira na aldeia do Maracanã: "[...] vi todo o gentio machos e fêmeas pequenos e grandes dizendo [...], se queriam retirar do sítio em que viviam, e queriam largar a companhia dos brancos, e ausentar-se para o mato [...]."25

O capitão índio Tomé também fora até o convento dos mercedários em Belém e, segundo o provincial da ordem, Frei Marcos da Natividade, pedira ao frei que, juntamente com os outros prelados das demais religiões, fizesse repor o seu Principal que o Padre Antônio Vieira havia aprisionado no Colégio. O frei pediu-lhe que procurasse os oficiais da Câmera. $\mathrm{O}$ capitão índio, então desamparado, disse-lhe que voltava para sua aldeia. Aproveitando a oportunidade, o provincial solicitou, por estar a caminho do Maranhão, algum guia de sua aldeia. A resposta do capitão índio foi estratégica - disse que não poderia achar o dito guia, pois os índios estariam levantados e metidos nos matos. Vendo-se obrigado, foi-se o frei à aldeia que encontrou quase despovoada. Diante disso, o frei afirmou aos índios que iria, juntamente com o provincial dos carmelitas e com o comissário do Santo Antônio, apresentar ao governador D. Pedro de Mello as desconsolações que padeciam em função da prisão de seu Principal. ${ }^{26}$

Frei Marcos também menciona que o capitão João Fernandez, que tinha assistido nas salinas de Sua Majestade "beneficiadas" por esses índios, afirmou que iria ao capitão-mor e provedor-mor da Fazenda Real solicitar uma solução, já que os índios não mais estavam nas salinas. Os índios haviam dito que, caso os dois não retornassem, iriam para o mato. Esse capitão, curiosamente, era genro do Principal Lopo de Souza. Outra testemunha, de nome Antônio de Mattos de Sampaio, afirmou que o Principal Lopo de Souza teria sido iludido com uma carta entregue pelo Padre Francisco Veloso, escrita pelo Padre Antônio Vieira, mandando chamar o Principal para o Pará com falsos afagos. ${ }^{27}$

O depoimento de Antônio Mattos de Sampaio traz outros detalhes sobre a prisão do Principal. Segundo ele, por informação de Frei Marcos, quando o

\footnotetext{
24BNL, Coleção Pombalina, PBA 645, f. 527 v.

${ }^{25} / \mathrm{dem}$, Ibidem.

${ }^{26} / \mathrm{dem}$, Ibidem f. 528

${ }^{27} / \mathrm{dem}$, Ibidem.
} 
Principal foi preso pelos jesuítas, lhe teriam tirado o Hábito de Cristo, dandolhe empurrões com violência e, ao o desarmarem, tomaram-lhe o bastão, lançando-o fora. $\mathrm{O}$ aspecto simbólico dessa atitude era muito forte. Era uma verdadeira afronta, o que possivelmente tornou o episódio muito mais dramático. Antônio Mattos também menciona algo que talvez possa explicar o verdadeiro motivo da prisão de Lopo de Souza por Vieira. Segundo ele, tudo teria acontecido porque o Principal não quis consentir com o governo temporal dos padres da Companhia naquela aldeia, apenas com o espiritual. ${ }^{28}$

Todos os testemunhos são unânimes em confirmar a decisão que os índios teriam tomado de abandonar sua aldeia. Ao contrário do que poderia parecer, antes de ser mais uma conspiração produzida pelas ordens religiosas e pelos membros do governo colonial, o episódio revela aspectos elucidativos sobre o tipo de prática que esses índios cristãos eram capazes de exercer para salvaguardar seus interesses. Os mesmos índios guardaram a suposta carta de Vieira e a anexaram a sua representação, pretendendo provar com isso a armadilha feita pelo jesuíta contra o seu líder. Segue transcrição da suposta carta do missionário:

[...] sinto estejais tão falto de saúde, mas são achaques da velhice, e lembranças que Deus vos dá, para que disponhas vossa alma, como quem sabe que há outra vida isto é o que desejei sempre de vós, e isto só o que deveis crer sempre de mim sem dar crédito a outras marandubas, que são coisas que me não passam pelo pensamento [...] parece-me muito bem que nos ajustemos como desejais, e suposto que não tendes canoa podeis vir na do vosso padre Francisco Veloso a quem vos queira trazer nela e seja antes de eu me partir para o Gurupá [...] porque em tudo o que for justo vos hei de ajudar, no que puder: Deus vos guarde a vós de sua graça como desejo [...] Antônio Vieira. ${ }^{29}$

Caso a carta seja mesmo de Antônio Vieira, o que é bastante plausível, fica patente a armadilha produzida pelo jesuíta para prender o Principal. ${ }^{30}$ Por outro lado, pelos testemunhos variados, não parece verossímil a afirmação do jesuíta de que o tal Principal praticava rituais canibais ou que vendia índios aos seus comparsas, como quis fazer parecer na outra carta enviada ao rei. Eventualmente, até poderia acontecer a venda de escravos, mas a importância do comércio do sal a tudo isso suplantaria. Ao mesmo tempo, embora tanto as outras ordens religiosas quanto as autoridades coloniais tivessem interesse em desacreditar o jesuíta por sua atitude contra a escravização dos índios, neste caso, não parece que sua preocupação fosse maior em combater seu inimigo jesuíta do que em perder um entreposto tão importante — seja para o comércio

\footnotetext{
${ }^{28}$ BNL, Coleção Pombalina, PBA 645, f. 531.

${ }^{29}$ Idem, Ibidem, f. 529.

${ }^{30} \mathrm{O}$ documento é um traslado feito já no século XVIII de outro escrito na mesma época do documento original. Esses documentos foram averiguados por todas as autoridades por que passaram e, mais importante, pelo governador Pedro de Mello. Ao mesmo tempo, toda essa documentação foi enviada ao jesuíta que, de posse dela, poderia ter negado a autoria e afirmado a falsidade da carta na correspondência que enviou ao rei, na qual conta o acontecido - o que não fez.
} 
do sal, seja para o abastecimento das canoas e da própria infantaria. A petição feita pela Câmara do Pará pode esclarecer a importância que o controle dessa aldeia tinha para o governo da capitania e, ao mesmo tempo, a importância de se manter como aliado o referido Principal. Falam sobre a sua prisão:

[...] Lopo de Souza da aldeia do Maracanã dizem o prendera o Reverendo Padre Antônio Vieira e o mandara em uns grilhões para Gurupá donde resultou grande escândalo ao povo deste Estado, principalmente aos índios naturais dele, e porquanto o dito índio nos consta ser um grande servidor de sua Majestade, e estar situado em uma parte que é estrada dos que navegam desta cidade para o Pará, e fabricarem umas salinas de sua Majestade de que resulta um grande bem aquele Povo, e aumento a fazenda de Sua Majestade, ordinariamente a infantaria se valem (sic) de mantimentos da dita aldeia, e por causa da sua prisão pode suceder uma grande ruína [...] pelo que pedimos a V.S.a [...] mande tomar informação do caso e vir o índio perante V. S.a para que requeira de sua justiça, V. S.a lha faça como todos esperamos [...]. ${ }^{31}$

A encruzilhada tensa que teve lugar no momento da expulsão de Vieira serve como marco da primeira etapa das relações entre as ordens religiosas, as autoridades coloniais e os índios cristãos no início da segunda metade do século XVII. Nos textos de Vieira, imperam ideias ligadas a uma conspiração contra as ordens d'El rei e contra os interesses cristãos, os quais as "estrelas guias" jesuítas eram as mais abalizadas a defender. Olhando de perto, no entanto, as coisas se complicam. $\mathrm{O}$ intrincado jogo de interesses era bem mais complexo. Os documentos sobre o episódio que envolveu a prisão do velho Principal revelam um conjunto de estratégias que os índios já batizados cristãos exerciam para fazer valer seus interesses, ainda que fosse uma autonomia diminuta. Mesmo assim, possuíam algum poder de barganha. $\mathrm{O}$ argumento de abandonar a aldeia e a consciência da sua importância para a comunicação entre as capitanias e como provedores do sal que abastecia o comércio externo evidenciam, sem dúvida, sua refinada estratégia política. Por outro lado, o papel representado por Vieira no episódio demonstra outros aspectos de não menor importância para o entendimento do jogo de poder que a Companhia exercia naquele momento.

Por trás das razões apresentadas por Vieira ao rei, estava a mais importante. A aldeia do Maracanã, que já existia antes da chegada do jesuíta e que fora destinada ao controle real, era administrada por um Principal, antigo aliado da Coroa e detentor do Hábito de Cristo. Esse mesmo Principal recusou-se a ser administrado no temporal pelos missionários da Companhia de Jesus. Certamente, uma afronta aos interesses da instituição e, mais ainda, aos interesses do Superior das Missões e amigo do rei, o Padre Antônio Vieira. Lopo de Souza, ao longo dos anos em que foi líder de seu povo, estabeleceu relações de convivência amigável com os portugueses que, naturalmente, deveriam

${ }^{31}$ BNL, Coleção Pombalina, PBA 645, f. 529-529 v.. 
envolver o respeito a interesses mútuos. Ele estava estrategicamente bem situado no jogo das relações de poder na região. Vieira interferiu nesse jogo de poder de uma forma aparentemente equivocada. O jesuíta avaliou mal as consequências de sua atitude. Criou um problema real para o abastecimento de sal, para o comércio e para as comunicações entre as duas capitanias.

O parecer do Ouvidor Geral é bem enfático quanto ao caminho que deveria ser tomado naquele caso. Afirma que o Principal Lopo de Souza era muito zeloso no serviço de Sua Majestade e era de grande utilidade para a sua fazenda. Além disso, fazia fabricar as salinas que socorriam todas aquelas partes, inclusive a cidade do Pará, sem nenhum dispêndio da Fazenda Real. Ao mesmo tempo, desempenhava um papel essencial em sua aldeia, possibilitando às canoas, que trafegavam de uma capitania a outra, pouso e escala. Em sua opinião, a prisão do Principal causava duas principais perdas: a das salinas e a perda de "nossa santa fé católica no que a paixão do Padre Antônio Vieira não deu lugar a fazer reparo". Causaria também enorme prejuízo à Fazenda de Sua Majestade. Conclui dizendo que, por serem os índios gente muito resoluta, caso não retornasse

\section{Caso a carta seja mesmo de Antônio Vieira, o que é bastante plausível, fica patente a armadilha produzida pelo jesuíta para prender o Principal}

seu Principal à aldeia, iriam para os matos e tudo ficaria perdido e desamparado. Por isso, era de parecer que o governador mandasse soltar da prisão o Principal Lopo de Souza e que ele fosse levado a sua aldeia sem demora. E, na eventualidade de ele ter culpa, esta seria averiguada e, conforme as leis, seria punido, mas enfatiza: "[...] sem ódio nascido das ambições." 32

Parte da historiografia afirma que o governador Pedro de Mello, antigo aliado de Vieira, foi um traidor da causa jesuítica. Essa historiografia se baseia nos relatos jesuíticos, incluídos os do próprio Vieira e de José de Morais. Há exagero nessas afirmações. O certo é que o governador se encontrava em uma situação delicada na posição de aliado de Vieira e, ao mesmo tempo, governador do estado, o que fazia dele representante do rei, mas também um defensor dos interesses dos seus habitantes. Sua posição fica nítida quando toma a decisão sobre o caso de Lopo de Souza.

Com cuidado, o governador definiu o seu parecer. Não seguiu o do Ouvidor Geral. Mandou ser trazido ainda preso ao forte do Pará o Principal Lopo de Souza e pediu ao Padre Antônio Vieira que remetesse suas culpas, para que fosse castigado. Reitera o pedido, por mercê, a Antônio Vieira. No documento, deixa escapar: "[...] mandará uma canoa com as pessoas que lhe parecer com esta minha ordem digo minha petição, e não quero dizer ordem ao Padre Antônio Vieira para que me mande entregar o dito

32BNL, Coleção Pombalina, PBA 645, f. 533. 
Principal." ${ }^{33}$ Ao mesmo tempo em que emitiu o seu parecer, também escreveu uma carta ao jesuíta. Num tom quase de súplica, disse que escrevia:

[...] para pedir a Vossa Paternidade com todo o extremo que Vossa Paternidade me faça muito querer mandar entregar o Principal da aldeia do Maracanã Lopo de Souza preso para se me ter no forte desta cidade pelas razões e protestos, que [...] Vossa Paternidade verá pelo traslado dos papéis que com este vão, onde será castigado por quem competir e este meu intento, não é mais que a fim de evitar os danos que do contrário podem resultar, dando se lhe o castigo que merecer [...] torno outra vez a pedir a Vossa Paternidade isto por mercê por evitar o que relato $[. . .]^{34}$

Esse episódio apresenta o intrincado jogo de poderes e a arquitetura política complexa que se produzia na região. Nela, o papel dos índios cristãos não era pequeno. Afinal, quem confrontou mais profundamente os poderes do Superior dos jesuítas, antes das autoridades, dos prelados das outras religiões e da própria Câmara, foram esses "resolutos" índios.

\section{Considerações finais}

O discurso jesuítico, cristalizado por uma historiografia simpática à piedade missionária, contrasta-se com outros que revelam diferentes vozes. Essas vozes, apesar de reproduzidas pela letra do poder, trouxeram outra "invenção" dos fatos. No texto de Vieira, destaca-se a contradição entre a ideia de liberdade apregoada pelo missionário e aquela que os índios cristãos escolhiam ao buscaram a casa de algum proprietário, tornando-se escravos e abandonando a missão. Alheios à defesa de suas almas, os índios cristãos preocupavam-se com a defesa de seus corpos. A liberdade que o Ocidente lhes impunha estava distante do movimento solto e amplo de seus costumes ancestrais. Antes de serem livres nas aldeias missionárias, importavalhes vagar pelos rios, caçar, pescar, dormir em comunhão com seus parentes nas malocas sem paredes ou exercer sua prática sexual e matrimonial sem as incômodas interferências do discurso moralista cristão. Muitas vezes, em sua limitada margem de manobra, tomaram as rédeas de seus destinos escolhendo a escravidão em lugar dessa estreita liberdade. Afinal, escravos dos colonos, eram contraditoriamente mais livres.

Na missão, o espaço era mais controlado e o domínio se fazia de forma profunda - estendendo-se do corpo da missão ao corpo dos índios. Os gestos, as formas de andar, falar, morar e se relacionar sofriam modificações e impedimentos. Por essa razão, Lopo de Souza não podia ceder às intenções de Vieira em tomar para a Companhia o governo temporal de sua aldeia. Negociou com a administração colonial e com as outras ordens religiosas para evitá-lo. Vieira acusava o Principal de manter comportamentos estranhos à fé

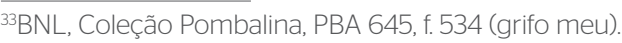

${ }^{34}$ /dem, Ibidem 
cristã, mas Lopo conhecia as regras do jogo: tocava os sinos, doutrinava seus vassalos para a colheita e preparo do sal, aceitava os rituais cristãos, fornecia remeiros e guias os viajantes. ${ }^{35}$

Antônio Vieira foi sendo construído pela historiografia jesuítica como um defensor intransigente das populações indígenas amazônicas. Ele, no entanto, não defendia essas populações; defendia a salvação de suas almas. ${ }^{36}$ Os corpos deveriam cumprir a exigência do trabalho nas aldeias e a disciplina moral cristã.

O poderoso amigo do rei, conhecido por sua feroz retórica em várias cortes europeias, temido e respeitado pelos seus inimigos, foi vencido pelo Principal Lopo de Souza. O velho índio soube escapar às armadilhas do grande orador. No jogo das ações políticas, no estreito lugar de sua pequena autonomia, venceu a guerra em defesa de sua singular liberdade.

\footnotetext{
${ }^{35}$ Sobre a relatividade desse domínio espiritual, ver: Ronaldo Vainfas, A heresia dos indios - Catolicismo e Rebeldia no Brasil colonial, São Paulo, Companhia das Letras, 1995. Sobre rituais combatidos como heresias no século XVIII na Amazônia Portuguesa, ver: Carvalho Júnior, "Visão do Diabo - crenças e rituais ameríndios sob a ótica dos jesuítas na Amazônia Colonial - séculos XVII e XVIII", PPGAS, Amazônia e outros temas: coleção de textos antropológicos, Manaus, EDUA, 2010, p. 159-194; e "A magia do novo - índios cristãos nas fronteiras da Amazônia Colonial", Nuevo Mundo - Mundos Nuevos, Debates - EHESS, 2011. Disponível em: <http://nuevomundo.revues.org/62258>. Acesso em: 08/10/2013

${ }^{36}$ Sobre a ideia de salvação de si através da salvação do outro, ver: Charlotte Castelnau-l'estoile, "Salvar-se, salvando os outros: O padre António Vieira, missionário no Maranhão", Oceanos, n. 30/31, Lisboa: Comissão N. para a Comemoração dos Descobrimentos Portugueses, abril/setembro, 1997, p. 55-64
} 